\title{
Changing religious landscapes challenge confession-based state policies on religion
}

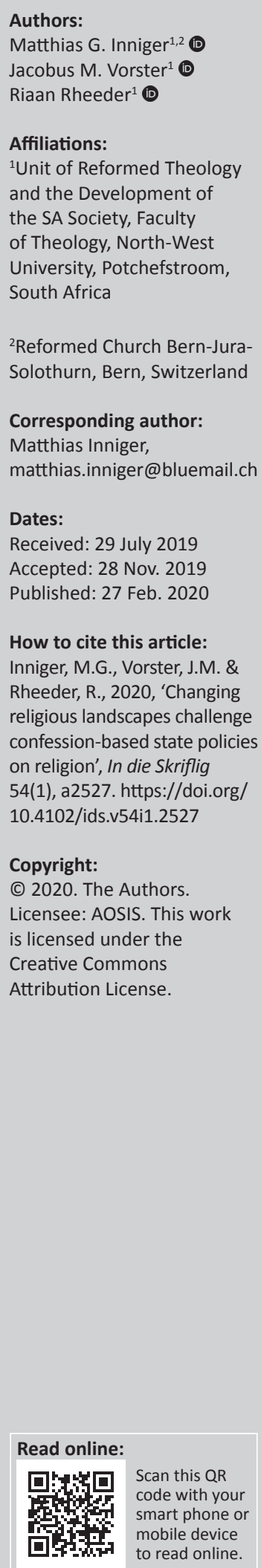

In contrast to state-religion systems of separation, many European states have a confessionbased policy on religion. This describes the relationship of the state to one or more preferred state-recognised religious confessions. State recognition, or preferential treatment of the chosen religious confessions, can occur in many variations. These preferred confessions are predominantly the (former) Christian state churches. Such policies date from a period when Christian state churches involved a major part of the population. In view of changing religious landscapes, traditional confession-based policies have developed an exclusive character. These policies include only chosen declining religious groups, while they exclude groups that have gained social relevance. Notwithstanding the new situation, many governments have hitherto failed to address the need for the adjustment of their policies on religion. Unadjusted policies are unsuitable to deal creatively with religious diversity in today's society. Governments that treat religious communities differently come into conflict with state neutrality and religious peace. This article opens the door to a six-part study, arguing that confession-based state policies on religion should incline towards greater inclusiveness. It is in the state's best interest to mobilise the positive potential of all religious-sociological groups. This article specifically focuses on the changes that are becoming apparent in today's religious landscapes and how these changes challenge traditional confession-based policies. It lays the foundation for the subsequent articles as a case study and a new conceptual framework for a fair, progressive and peacebuilding policy on religion for the Swiss Canton Bern.

Keywords: changing religious landscapes, confession-based policy on religion, public peace, state neutrality, state (non-) recognition of religious communities, social potential of religious communities, Swiss Canton Bern.

\section{Introduction}

\section{Traditional confession-based state policies on religion are reaching their limits}

Traditional confession-based state policies on religion reflect the fact that a state has a relationship with one or more preferred confessional groups to which it grants privileges (Portier 2017:212). These preferred groups traditionally are (former) ${ }^{1}$ Christian state churches. Confession-based policies, which have a long tradition in the European context, ${ }^{2}$ exclude churches and religious communities beyond those that have been recognised by the state. Portier (2017:212) mentions Greece, the United Kingdom and Denmark as typical examples of states with confession-based policies that have an exclusive relationship with chosen churches by established law. In contrast to these states, France employs a system of separation where the state has no relationship with any religious community. ${ }^{3}$ Belgium and The Netherlands employ systems that combine the system of confessionalism and the system of separation (Portier 2017:212).

In Switzerland, ${ }^{4}$ to which this study mainly refers, the majority of cantons have, again for historical reasons, confession-based policies on religion. ${ }^{5}$ These cantonal governments each have a relationship to one or more Christian churches. ${ }^{6}$ Swiss cantonal confession-based policies on \footnotetext{
1.In some contexts, these churches are still state churches (e.g. Denmark). In other contexts, they are no longer state churches (e.g. Sweden).
}

2.Compare the long shadow of the past: Contemporary Europe's confessional structure (Madeley 2003:27-48).

3.However, in Alsace-Lorraine, churches are, in contrast with the most of French departments, publically established.

4.Switzerland has delegated issues of the state-religion relationship to the level of the 26 cantons. As a result, Switzerland has 26 'small states', and therefore 26 different policies.

5.Only the Cantons Geneva and Neuchatel have a state-religion system of separation.

6.Non-Christian religious communities are generally not state-recognised in the Swiss context. Only a few Swiss cantons have a relationship with non-Christian communities, for example with Jewish communities (Kanton Bern 2018a). 
religion developed in the 19th century when liberal governments gave public-legal recognition to state churches. Even if this was an attempt to keep churches at bay, churches appreciated this step, as it involved privileges such as state subsidies or access to chaplaincy in public institutions.

While confession-based policies played a comprehensive role for decades, because they included the majority population, these policies have today lost their inclusive character. They do not consider new sociological groups of the religious landscape, namely churches and religious communities unrecognised by the state, and the nondenominational part of the population. Considering that churches and religious groups beyond the state-recognised churches have the potential to contribute to the common good of society (Göransson 2014; Inniger 2018:5-6; Schuppert 2017:136-137, 168-172), and that many of these groups have expectations regarding an appropriate chaplains' service in public institutions as well (Inniger 2018:13), ${ }^{7}$ it is inauspicious for governments to exclude them from state policy. This exclusion is inauspicious, particularly because governments expect that these groups support the states' religiouspolitical behaviours as well. Today's traditional policies do not consider the power and the potential of stateunrecognised churches and religious communities, nor do they do justice to the state's claim of being neutral ${ }^{8}$ regarding $^{\prime}$ religious issues. Unadjusted confession-based policies apply exclusively to a decreasing privileged part of society, while they ignore increasing groups whose potential should not be underestimated. As will be seen later in this article, traditional confession-based state policies on religion have reached their limits.

\section{Presentation of the upcoming study}

Given these facts, the present article opens the door to a sixpart thesis. This thesis argues for governments to develop historically orientated confession-based policies towards more inclusiveness, not only in view of their own interests, but also as the benefit of the positive potential of all religious communities, and as furthering social cohesion and public peace among religious communities. The argument is furthermore that unadjusted policies on religion share responsibility for potential negative developments regarding ecumenical, interreligious and social relations, as they reinforce asymmetries between social groups (Inniger 2018:26). In view of this thesis, reconsidered principles and well-balanced models for timely policies are necessary. The line of argumentation pursued in this thesis, is based on premises that are closely related to my professional background. I analysed the religious landscape in the Swiss Canton Bern for the government. At the same time, I am a

7.In The Netherlands, the humanistic involvement in chaplaincy has been a fact since 1964 (Fisher 2009), and the involvement of non-Christian chaplains in public institution is well-established (Inniger 2016:67-69).

8.In this regard, Engi (2017:16) draws our attention to the fact that the term neutrality originates from ne-uter, which means 'neither of them': If the state is neutra regarding religious issues, it is not part of any religious group. Such neutrality does not necessarily imply absolute equal treatment of all groups, but it implies that not necessarily imply absolute equal treatment of all groups, but it implies that states do not identify with specific religious bodies, and that citize
state policy on religion as fair and plausible towards all groups.
Christian theologian in the state-recognised Reformed Church of the Canton Bern. As both a citizen of this Canton and as a Christian theologian, I emphasise minimisation of ecumenical and interreligious asymmetries, fair treatment of all religious communities by the state, and promotion of social justice, social cohesion and social peace. I recommend implementing principles I have previously specified from a Swiss Protestant view (Inniger 2016:38-55). These principles stress the commitment to ecumenical, interreligious and social dialogue. They accentuate respect and empowerment for socially weaker groups and building bridge activities in civil society.

A case study on the Swiss Canton Bern can support governments, administrations, politicians and professionals in their search for a timely policy. The Canton Bern serves as an example because the change in the religious landscape challenges its historical policy. The government is faced with a necessary reconfiguration of the state-religion relationship (Ecoplan, Ad!vocate 2014; Inniger 2018; Kanton Bern 2018b). Regarding the policy of the Canton Bern, a reconsidered policy should be fair, progressive and peacebuilding. It should be fair because the state should embrace 'multipartiality', and fair treatment of all religious communities (Engi 2017:16; Inniger 2017:127; Kanton Bern 2018c; Swiss Federal Supreme Court 1992:BGE 118 Ia 58; United Nations 2018:Art. 6 \& 18). Moreover, it should be progressive because the state should consider the responsibility of positively influencing developments around religious communities and the social potential of all religious groups (Engi 2018:art. 34; Schuppert 2017: 136-137, 168-172). It should also be peacebuilding, because it should facilitate the participation of all religious social actors in civil society, as well as the importantly, peaceful coexistence between different religious groups and the population not aligned with any specific religious organisation (Baumann \& Stolz 2007; Bochinger 2012; Inniger 2019). The case study, which includes a topical evaluation and theological-ethical perspectives, builds its discourse on general observations, issues and options available for approaching existing problems. It discusses criteria, principles and optional models and defines a concept of state neutrality and state responsibility regarding religious issues with a view to the Universal Declaration of Human Rights. The research attempts to make elements of the recommended model available for other contexts.

This first article specifically considers relevant changes on the religious landscape and the corresponding challenges this holds for confession-based policies. It focuses on issues caused by changing religious landscapes, the role of all religious communities in civil society and the role of governments themselves, regarding the peaceful coexistence of groups, including those with no affiliation. The specific focus on the confession-based state policy on religion of the Canton Bern, is already evident in this article. 


\section{Changing religious landscapes Today's religious landscapes are 'Christian, secular and plural' (Weller)}

The following section outlines the socio-religious phenomena within the changing religious landscapes that have an impact on traditional confession-based state policies on religion.

In the wider European context (Appel et al. 2012; Bühlmann, Bühler \& Kessler 2009; Friedli \& Schneuwly Purdie 2004), religious landscapes are no longer homogenous; they are Christian, secular and plural (Weller 2005:71). Even if traditional state-recognised Christian churches still flag dominance in many contexts and their influence still characterises the religious landscapes, people's alienation from these churches is clearly noticeable, concomitant with both an increasing religious diversity and a growing nondenominational part of the population. Alienation from state-recognised churches may be attributed to the phenomenon of individualism and secularisation, and on the fact that some people no longer identify with state-recognised churches. It is also influenced by the increasing religious diversity mainly caused by migration. Because of these trends, state-recognised churches become 'poorer, older and smaller' (Stolz \& Ballif 2010).

The Swiss context exemplifies these developments. While in 1910, the traditional state-recognised churches included $98.7 \%$ of the population, in 2016 this had dwindled to only $61 \%$ of the population, indicating a clear downward trend (Inniger 2018:8). This development is even more pronounced in The Netherlands, where traditional churches included $92.3 \%$ of the Dutch population in 1909, while today they include only $39 \%$; in the same period, the non-denominational part of the population has increased from 5\% to 50\% (Knippenberg 1992; Statistics Netherlands CBS 2018). In some Swiss contexts, the non-denominational group has also developed into the largest of the religious landscape, for example in the Swiss Canton Basel-Stadt (Kanton Basel-Stadt 2019).

\section{Alienation from state-recognised churches}

Due to the phenomena of individualisation and secularisation, many people have become alienated from state-recognised churches. Many people no longer identify with state churches. They perceive themselves as autonomous individuals, whether they are religious or not. Moreover, many people no longer accept statements of religious institutions in an uncritical way. When the Catholic pope stated in 2018 that abortion equals 'contract killing' (Tagesschau.de 2018), a group of six well-known Swiss personalities left the Catholic Church in protest, because they could no longer identify with such statements (Hehli 2018). The phenomenon of individualisation, and the state-recognised churches' lack of identification, potentially promote the alienation of many people from these churches. The phenomenon of secularisation ${ }^{9}$

9.This study does not understand secularisation as the 'opposite of religion' (Kleine \& Wohlrab-Sahr 2016:3); rather a secularist attitude includes that the state and Wohlrab-Sahr 2016:3); rather a secularist attitude includes that the state and
religious communities are distinguished, and that life without state-recognised churches becomes increasingly common. also promotes the alienation of many people from staterecognised churches. Today's religious landscapes are characterised by citizens who distinguish between state and religion as much as states and governments do. Christoph Neuhaus, the former Director of the Church Department of the Canton Bern, mentions that the secular state should not identify with one specific religious group; rather it should grant parity, by taking the necessary distance from religious institutions (Kanton Bern 2018c). Engi (2017:16) confirms that secular states should have a proper distance from all religious communities. A state separated from religion and private life without state-recognised churches, have become common.

\section{The non-denominational group}

Alienation from state-recognised churches leads to the growing non-denominational population. The umbrella term non-demoninational group is, however, questionable. This religious-sociological group must be differentiated (Inniger 2018:13). Even if it includes many people, who in fact have no religious affiliation, this group further includes people who are believers and worshippers, and who are overlooked because some official registration systems are simplifying things. In the Swiss Canton Bern, for example if people are not members of state-recognised religious communities, they are automatically categorised in the non-denominational group. If they join free churches, ${ }^{10}$ other unrecognised Christian churches or non-Christian religious communities, they still belong to the group of people with 'no denomination'. From the point of view of the Canton Bern, believers or worshippers who no longer support state-recognised churches, who have renounced traditional doctrines, religious practices or political opinions of state churches, who have been disappointed by their church, or who just find their own way of religion, spirituality and emotional support are officially deemed to be 'without denomination'. This study considers the non-denominational group and their role regarding state policies on religion, in a more nuanced way.

\section{Religious diversity}

In the European context, religious diversity primarily includes diversity regarding Christianity, Islam, the Jewish faith, Buddhism, and Hinduism. Religious diversity includes further an increasingly diverse Christianity itself. In many states with traditional confession-based policies, this diverse Christianity involves state-recognised churches as well as a wide array of churches that the state does not recognise. In the Swiss Canton Bern, the unrecognised churches are the traditional and new free churches, moreover the Anglican Church, the Lutheran Church, the Orthodox Churches, and the great variety of churches emerging from migration. Religious diversity has certainly evolved because people do leave state-recognised churches to join other religious

10. Free churches are Christian churches that are not recognised by the government in states or cantons with confession-based policies on religion. In Switzerland, this states or cantons with confession-based policies on religion. In Switzerland, this
includes, for example, the Baptists and the Methodist Church, or the Salvation Army (Freikirchen.CH 2019). 
communities. Nevertheless, religious diversity primarily evolved because of migration (Bramadat 2009:1-26). The immigration of people from a variety of Christian, Muslim, Hindu, Buddhist and other religious backgrounds has increased religious diversity, both interreligious diversity and Christian-ecumenical diversity.

\section{Key findings}

Even if a considerable part of the population alienate themselves from the traditional churches, the (former) state churches still characterise today's religious landscapes. Furthermore, state-unrecognised churches and non-Christian religious communities are growing, with the result of an increasing religious diversity. The non-denominational part of the population is increasing at a rapid pace. This development challenges traditional confession-based state policies on religion.

\section{Challenges confronting confession- based state policies on religion New awareness of governments regarding policy on religion}

In view of changing religious landscapes, governments have become aware that traditional confession-based policies on religion focus in an exclusive and backward-looking way on the decreasing state-recognised churches, while they do not consider new stakeholders of policies or their social potential.

Governments and states are faced with new questions: How can they do justice to the fact that religion and religious communities continue to exist in post-secular societies (Habermas 2018:13)? What can they take from the fact that religion is not only a private but also a societal matter? How can they include religion in their overall political conception? ${ }^{11}$ How can they assume responsibility for social cohesion, religious peace and a properly functioning 'robust civil society' (Van Bijsterveld 2018:21)? How can they avoid the discriminating effects of unequal treatment of state-recognised and unrecognised groups? How can they avoid blocking effects of this policy on social cohesion (Inniger 2018:25-26)? How can they keep the different treatment of religious groups from furthering a two-class society (Inniger 2018:25)? How can they be neutral regarding all religious communities? How can they define the term neutrality? How can they treat all religious groups fairly? How can they mobilise the positive potential of all religious groups? How can they promote the feeling of belonging among churches and religious groups, in order to avoid negative outgrowth of religion?

The two main implications of the changing religious landscape for confession-based state policies are specified in the next section, followed by the identification of concrete challenges.

11.I refer to the explicit inclusivity of religion in Article 15.2 of the Constitution of the Republic of South Africa. Religious observances may be conducted at state or stateRepublic of South Africa. Relyous observances may be conducted at state or stateaided institutions, provided that those observances follow rules made by the appropriate public authorities that they are conducted on an equitable basis, and that attendance is free and voluntary (Constitution of the Republic of South Africa 2019).

\section{The new constellation of stakeholders of policies on religion}

States with traditional confession-based policies on religion are currently challenged by an evident religious diversity (Inniger 2018:11-12). Religious diversity has huge implications for state governance of diversity. What is true regarding governance of societal diversity in general, is specifically true for governance of religious diversity. The positive connotation of diversity - also of religious diversity - has been outlined in an Austrian lexicon on political issues (Politik-Lexikon.AT 2019):

The term diversity describes variety and plurality. ... Regarding socio-political contexts diversity describes ... the variety and plurality among people. ... Society develops in increasingly colourful ways: people have different religious, political or ideological worldviews, they have different ethnic backgrounds, they live under different conditions, they possess various talents and they speak different languages. Diversity presents a great opportunity. Making politics regarding diversity means benefiting from these opportunities. This is a process, in which all are involved; everybody participates in this process, everybody supports the development of this process ... Diversity management refers to the focused use and promotion of diversity ... [author's own translation].

The increasing religious diversity of the current religious landscape, seen here as a 'great opportunity', enriches society, and at the same time, it challenges state governance. Governments ask how traditional confession-based policies on religion should be transformed into appropriate instruments that deal with religious diversity within society creatively. Governments become aware of the new constellation of stakeholders. Even if state-recognised churches remain important, confessional and nondenominational ${ }^{12}$ groups outside state-recognised churches must be considered as relevant policy stakeholders as well.

According to Inniger (2018:6, 25), governments should create a capacity of know-how about these diverse stakeholders, including know-how about religion, religious landscapes, mapping of religious communities, dialogue with all stakeholders and multifaith chaplaincy in public institutions. In this respect, Van Bijsterveld (2018:152) recommends that governments get to know all religions without excluding any denomination. Governments should then include the new stakeholders in their policy on religion. If unrecognised, confessional and religious groups are excluded from the policy, and they cannot fully participate in civil society in the same way as state-recognised churches. States that cooperate with preferred religious groups, implicitly include these groups in public, civil and political life. Lack of recognition, acceptance, resources, access to chaplaincy and participation in civil society, however, pushes stateunrecognised churches and religious communities back into an existence of backyards and cellars (e.g. Ballmer 2019; Inniger 2018:20).

12.The Dutch Constitution guarantees regarding the non-denominational population, freedom of belief as well as freedom of religion (Van Bijsterveld 2018:25). 


\section{The social potential of all religious communities: Religion as a fire that warms or that burns}

Changed religious landscapes also have implications for state policies on religion regarding the social potential of all churches and religious communities. In this regard, it is important to state that implicitness of religious freedom has been considered for decades only in relation to its individual implication. Every citizen may choose his or her faith, nonfaith or belief. Van Bijsterveld (2018:11) notes that if states consider religious freedom by only considering the individual implications, and if they label religion exclusively as a private matter, this is far from reality. Religion has significance as a societal matter (Göransson 2014; Inniger 2018:5-6; Schuppert 2017:136-137, 168-172; Van Bijsterveld 2018:12). In this respect, Blume (2017:147) picks up the words of Rabbi Jonathan Sacks, who mentions that states should deal with policy on religion as guardians of fire. Referring to the positive and negative potential of religion, he sees religion as a fire that can warm individuals, groups and society, but also a fire that can burn.

With regard to the warming fire, governments and staterecognised churches support studies that make clear the relevant contributions of state-recognised churches to the common good (Ecoplan, Ad!vocate 2014). Inniger (2018:15-17) points out that state-unrecognised churches and religious communities contribute to the common good of society as well. When they give a home and security to people, when they support integration, education, interreligious dialogue, social work and cultural development, they are warming fires. The contribution of all religious communities as warming fires is so obvious, that the state of Sweden supports all religious communities with the idea that they can contribute to the common good in a positive way even better when they are supported by the state (Göransson 2014; Sweden 2018a; 2018b).

Regarding the fact that religion can also be a burning fire, the Swiss Canton Zurich mentions that religion can have - besides the many positive and valuable social contributions negative effects on society (Kanton Zürich 2017:12-13). In this respect, Van Bijsterveld (2018:14) confirms that religious communities can cause societal problems such as radicalisation or dropping out of society. Inniger has demonstrated that a lack of state recognition, a lack of social acceptance, a lack of resources and access to chaplaincy, and a lack of participation in civil society can push unrecognised churches and religious communities back into backyards and cellars (e.g. Ballmer 2019; Inniger 2018:20). Such conditions of existence do not further the positive potential of churches and religious communities.

In view of the positive and the negative social potential of all churches and religious communities, Schuppert (2017: 136-137, 168-172, 185) recommends that all religious communities should be considered as governance actors and possible power factors. All religious groups are legal communities of identity and communication; all of them have a capacity for acting collectively: transnational, institutional and law-making power turns them into highly relevant actors regarding the state. Whether the state cooperates with state-unrecognised churches and religious communities or not (Schuppert 2017:183-187), the state is confronted with these groups with social potential that have yet to be included within and respected by policies on religion. In this respect, Schuppert (2017:197) recommends an extension of constitutional law on religion to include all stakeholders of today's religious landscapes.

\section{Concrete challenges}

Keeping these insights in mind, there is a cluster of concrete challenges for governments with traditional confessionbased policies on religion, due to the changes in religious landscapes.

The first concrete challenge is the exclusivity of policies. States with unadjusted confession-based policies exclusively focus on declining state-recognised churches. If states consider the social potential of all religious groups, if they aim to treat all groups fairly, and if they assume responsibility for social cohesion and peace among all religious communities, they will develop a policy towards a greater inclusiveness. States should include new stakeholders in their policy on religion.

The second concrete challenge is lack of knowledge and know-how among states and administrations. Government administrations and public institutions such as schools, prisons, hospitals, armies and migration services are faced with new issues regarding governance and the management of religious diversity, for instance in the cases of chaplaincy in public institutions, religious holidays and dietary rules (Inniger 2016, 2017:84-93). Parliamentary initiatives prove this fact (M. Koelbing [Political motions regarding religious issues] pers. comm., 12 July 2018). It is apparent that members of governments, parliaments, government administrations and public institutions have, up until now, generally lacked information and knowledge about religious issues, and a clear strategy regarding the social interaction of states with religious diversity (Inniger 2018:25).

The third concrete challenge is the questionable role of the state itself regarding the development of churches and religious groups. However, states themselves, due to their strategy of recognising some religious communities while ignoring others, reinforce questionable developments among religious-sociological groups. If a state distinguishes between two classes of religious communities (Inniger 2018:21), there are as a result, state-recognised and state-unrecognised communities. While the former class is socially credible in public perception, the latter experiences a lack of credibility. Religious communities are divided into privileged religious groups, rich in resources, and underprivileged groups. The negative effects of this development are obvious. Churches and religious communities not recognised by governments are excluded from the focus of governmental and social 
attention. Being an unrecognised church or religious community, often implies that it has no access to chaplaincy in public institutions; moreover, it is not included in state consultation processes, nor does it receive public funds or university training. If unrecognised communities want to publish services and events in public gazettes, they must subsidise these themselves, in contrast with state-recognised churches (Inniger 2018:20). Eventually churches and religious communities that are not recognised by the states, are exposed to the need to permanently justifying their community's existence (Inniger 2018:2).

The fourth concrete challenge is ignorance about the sharp increase of the non-denominational part of society. Governments do not include them in their religious-political considerations, even if they are relevant to policy. This part of society is well represented in governments, parliaments, in public institutions and among the voters. Its inclusion in religious-political considerations is increasingly important for future policies, which should support the necessary majorities in parliaments and among the whole population (Inniger 2018:13). Moreover, some citizens of this group would also like to have specific chaplains' services in public institutions. ${ }^{13}$

These, then, provide a summary of the clear cluster of challenges that confession-based policies face within a changing religious environment. There are new and relevant stakeholders that policymakers should consider and include, and there are concrete problems that must be solved. From the state's point of view, solutions for the following focal points are of the utmost importance: state responsibility and neutrality, and state recognition of religious groups.

\section{State responsibility and neutrality regarding religion}

In the past, when the only policy stakeholders were traditional state-recognised churches, the great majority of the population was included in the confession-based policy. Today, many churches and religious communities are excluded from the government's attention and policy. How can governments claim to be neutral if they include and exclude? How can governments be neutral if they offer state-recognised groups the possibility of participating in public life and civil society while they withhold this right from groups unrecognised by the state? How can they - in a neutral way - assume responsibility for a fair distribution of state money, equity of tax relief, chaplaincy in public institutions, meaningful consultation processes and the promotion of social cohesion, if they include and exclude?

Theoretically, governments with confession-based policies on religion, guarantee religious freedom and equal opportunities for all. In practice, however, states with confession-based

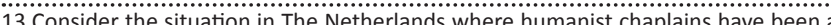
matter of course since 1964. See also the discussion of the parliament of the Canton Bern, where the current Director of the Church Department, Evi Allemann, Canton Bern, where the current Director of the Church Department, Evi Allemann,
mentioned that non-denominational people have also demands regarding chaplaincy (Kanton Bern 2018d). policies are so closely connected to one or more confessions (Doe 2011; Madeley \& Enyedi 2003; Robbers 2005), that they do not act in a neutral way. If, for example, the law of the Swiss Canton Basel-Land (Kanton Basel-Land 2018) states that only communities of Christian and Jewish religion can apply for state recognition, this violates the principles of equal treatment (Eidgenössische Kommission gegen Rassismus 2003:20), and state neutrality regarding religious affiliation. In this respect, Durham (2012:363) considers that states with a preferred set of religions do not offer an optimal form of religious freedom. State neutrality regarding religion remains challenged. In this context, Inniger (2018:25-26) points out that a lack of state neutrality furthers discrimination and hinders or even jeopardises social cohesion and promotion of religious peace. States that include and exclude from policies, themselves assume co-responsibility if the excluded churches and religious communities enter a vicious circle of non-acknowledgement (Inniger 2018:35). They cannot fully participate in social and political life, nor can they benefit from the privileges of recognised religious bodies. Without state recognition, support and privileges, they cannot achieve social recognition, and without social recognition, state recognition remains unreachable. Governments bear co-responsibility for this situation. By privileging certain churches and religious communities while ignoring others, a state policy brings about two classes of religious communities. There are doubts about whether states with unadjusted confession-based policies are, in fact, neutral regarding religious issues (Inniger 2018:30; Kanton Bern 2018c; Swiss Federal Supreme Court 1992:BGE 118 Ia $58)$, and whether they accept their responsibility for supporting social coherence and a robust society.

Governments have a clear influence on the coexistence of state-recognised and state-unrecognised communities (Kanton Bern 2018b: principle 8; Kanton Zürich 2017:20), and thus on the social cohesion of civil society. Ironically, they should start asking whether, as neutral states, they are not themselves driving a wedge between the two classes of churches and religious communities by enhancing inequalities between state-recognised and state-unrecognised churches and religious communities (Pfaff-Czarnecka 2009). Regarding these inequalities and asymmetries, their decisive role and responsibility is obvious (Inniger 2018:21-25).

\section{Recognition by the state}

Regarding the fact that states recognise some religious communities while refusing recognition to others, issues regarding the practice, application and utility of this legal form are increasingly coming into focus for critical debate. Does the state recognise chosen communities for historical reasons? Do young communities have a chance of being recognised? Is the criterion of tradition sufficiently for states to justify their policy? Is the insistence of state-recognised churches on historic rights and legal titles ${ }^{14}$ sufficiently for future policy on religion notwithstanding the fact that the 14.Issues of historic rights and legal titles will be a matter of discussion within the subsequent articles. 
religious landscape has changed? Does the state recognise chosen communities because of their size? Do small communities have a chance of being recognised ${ }^{15}$ Does the state - even if against human rights and constitutional principles ${ }^{16}$ - recognise only communities of Christian faith? If this is so, why are in the Canton Bern, several traditional Christian churches like the Anglicans, as well as the Orthodox, Lutheran and free churches not state-recognised? Is the criterion that state-recognised churches contribute to the common good of society sufficiently for a future policy on religion if one considers the fact that unrecognised churches and religious communities also contribute to the common good of society?

Currently, some governments are reconsidering the criteria of state recognition. They are considering other options of a state-religion relationship outside the traditional legal framework of state recognition (Inniger 2018:34-35). In 2000 Sweden has reorganised its law on religion to include all religious communities in the state policy (Sweden 2018a; 2018b). In Sweden, religious communities can register, and they are supported by the state even if they cannot yet give proof of a long tradition and a certain size and importance in society. For the state of Sweden, all religious communities are important, and if they still lack structure and relevance, they are especially in need of the state's support and attention. If they still lack social recognition, the state's recognition is especially necessary.

\section{The role of state-recognised churches}

State-recognised churches are also challenged by today's religious landscapes, particularly regarding the loss of members, relevance and resources - possibly also regarding reprofiling and reorganisation processes. Because they are still protected and nourished by the state, they share an elevated co-responsibility for the reconfiguration of state policies on religion (Inniger 2018:7, 19-20). They cannot defend monopolised and structural privileges as mere observers of the unfolding scenario of changes, as this scenario will affect them after some years. Their engagement for a more inclusive state policy on religion is in their own interest if - in the case of loss of members - governments should give up their commitment to state-recognised churches as well. Their role is to contend for the reduction of unjustified asymmetries between different religious groups, and for the inclusion of all religious stakeholders in a balanced partnership of state and all religious groups.

State-recognised Christian churches should consider these issues from a theological point of view. Theologically established ecumenical, interreligious and socio-dialogical principles have been specified for the Swiss Protestant context

15.In the Canton Bern, the Old Catholic Church and two Jewish communities are recognised by the state, even while they consist only of about 2000 members (Inniger 2018:10). In this case, the size of the group can hardly be a criterion for state recognition.

16.Article 8 of The Federal Constitution of the Swiss Federation prohibits discrimination on grounds of way of life, religious and ideological conviction (Schweizerische Eidgenossenschaft 2018:art.8.2).
(Inniger 2016:38-55). These principles stress a strong commitment to ecumenical and interreligious dialogue; they accentuate respect and the empowerment of socially weaker groups, and respect building bridges among social groups in civil society. Based on these principles, state-recognised Swiss Protestant churches should promote dialogue with churches and religious groups unrecognised by the state; they should support their state and social recognition; furthermore, they should be ready to share state benefits and access to chaplaincy in public institutions. The thesis to be developed in subsequent articles assumes that Christian theologians of state-recognised churches should recommend from their Christian perspective (Vorster 2007; Wolterstorff 2012), reconsidered principles and models for a fair, progressive and peacebuilding government policy on religion.

\section{Key findings}

Changes in today's religious landscapes have huge implications for traditional confession-based state policies on religion. These policies should develop towards more inclusiveness, according to the new religious landscape and the social potential of all religious groups. States are confronted by new policy stakeholders that should be considered as important when it comes to social cohesion and peace among religious groups. States are faced with concrete challenges, and initiatives of parliaments address these issues. State responsibility and neutrality, and state recognition of religious communities are crucial foci for critical discussion. State-recognised churches should urge governments to develop policies that are more inclusive.

\section{Outlook}

Various governments throughout Europe that assume responsibility for managing religious diversity, have already initiated changes in state policy on religion (Bader 2009:43-72; Koenig 2009; Kymlicka 2009; Pfaff-Czarnecka 2009). Sweden (Sweden 2018a; 2018b), Hungary (Constitution of Hungary 2011:Act CCVI:5; 2018), and Austria (Rechtsinformationssystem des Bundes 2019) have opened religious law to all religious communities. Other European governments and many Swiss cantonal governments are sticking to the strategy of their unadjusted confession-based policies. They continue to exclusively favour state-recognised Christian churches. Such historically orientated and exclusive policies treat unrecognised churches and religious communities differently from state-recognised churches (Kanton Bern 2018e). Numerous governments retain monopolistic and exclusively historically orientated policies, even if experts evince that numerous religious groups beyond state-recognised churches are relevant for states as well. Weller (2005:183-185) recommends the development of more inclusive and dialogical-creative policies on religion. He calls on governments to engage in dialogue with religious communities and to recognise the specificity of religion, which includes the transnational character of religion. Moreover, he calls on governments to avoid the systematic exclusion or marginalising of non-Christian religious groups. 
He recommends that they accept the new social reality, and he emphasises that it is vital for governments to promote interreligious dialogue (Weller 197-198).

The case study that will follow this article, focuses on the Swiss Canton Bern's policy on religion, as an example of an unadjusted policy that includes only chosen religious communities with a privileged status and treatment, while other religious communities are, at best, 'monitored' by the state (Inniger 2018:29; Kanton Bern 2018e). The church synod of the state-recognised Reformed Church of Bern still holds its meetings in the council hall of the cantonal government. The government of the Canton Bern still pays the salaries of the clergy, provides university training for the clergy and gives them access to chaplaincy in public institutions. It provides recognised churches with considerable financial assistance and includes them in the state's legislative processes by means of consultation. The Canton Bern even collects the taxes for the privileged churches. In the same canton, many Christian churches are ignored, unrecognised and unsupported along with the majority other non-Christian communities. It is obvious that mainly historical reasons are at the centre of this non-consideration of unrecognised religious communities. While religious communities, recognised by the state, were already present in the Canton Bern when the legislation of public and legal recognition was established in the 19th century, unrecognised religious communities settled in the Canton Bern only during the last 50 or 100 years. ${ }^{17}$ They are not as old as the recognised communities, nor do they have such a longstanding tradition. They lack state recognition, state privileges, state support and important accesses and therefore they were not able to gain as much ground as recognised religious communities regarding presence, dimension and social recognition. State attention, state support and enjoying access to civil society, institutions and political processes are, however, the preconditions for gaining presence, dimension and social recognition. Structural discrimination against unrecognised religious bodies is a given fact. The subsequent case study considers the specific religious-political situation of the Swiss Canton Bern. Current social and demographic developments are a reality, to which the Canton Bern will have to find adequate answers, by adjusting the traditional confessionbased state policy on religion towards more inclusiveness. This thesis aims to support this process.

\section{Conclusion}

As demonstrated, developments among socio-religious groups, whether they are currently included or excluded by states, challenge traditional confession-based policies on religion. If governments do not develop policies towards greater inclusiveness, unadjusted confession-based policies will continue to express an exclusive relationship between the state and one or more chosen religious groups, while these selected groups will sooner or later turn into social minorities. If less than $50 \%$ of the population belong to

17.The free churches of the Canton Bern are an exception. They have a long tradition in the Canton Bern. Their wish for state recognition has been refused by the government. state-recognised churches, unadjusted confession-based policies will be even more under pressure for justification than they already are today. Moreover, if governments do not adjust these policies, one may well infer that they themselves have a less than satisfying effect on ecumenical and interreligious relations, social cohesion and peace among religious communities. In view of today's religious landscapes, all socio-religious groups should be taken into consideration: all of them enjoy presence and relevance within the public sphere, and all have the potential 'to warm the society' by contributing to the common good. The thesis to be developed in subsequent articles will deal with a topical evaluation, and with recent research in this field (e.g. Ecoplan, Ad!vocate 2014; Engi 2017; Göransson 2014; Inniger 2018; Schuppert 2017; Van Bijsterveld 2018; Weller 2005). Based on this, it will develop a new conceptual framework for a fair, progressive and peacebuilding policy on religion, presented by the example of the Swiss Canton Bern, accounting Christian-theological considerations. This implies that this thesis also focuses on the issue, how state-recognised churches can develop in this reform phase towards newly profiled and vibrant churches.

\section{For indexing purposes}

Due to societal changes and demographic developments, states with confession-based policies on religion are being challenged regarding their inclusiveness, and their function of supporting the positive social potential of all religious groups. These issues challenge the Swiss Canton Bern, especially as traditional churches are losing members and relevance, and as religious diversity and the nondenominational part of society are increasing. A series of questions faces governments regarding religious issues. In consideration of state neutrality, state responsibility, state recognition and Christian-theological perspectives, a new conceptual framework for a fair, progressive and peacebuilding policy on religion is in demand.

\section{Acknowledgements}

Prof. Dr J.M. Vorster \& Prof. Dr A.L. Rheeder contributed as the promoters of the $\mathrm{PhD}$, from which this article is derived. Both, they commented the R.P., and Prof. Dr J.M. Vorster commented on this submitted article.

\section{Competing interests}

The authors have declared that no competing interests exist.

\section{Authors' contributions}

M.G.I. is the main author if this article. J.M.V. \& A.L.R. contributed as the promoters of the $\mathrm{PhD}$, from which this article is derived. Both commented the R.P., and J.M.V. commented on this submitted article.

\section{Funding information}

This research received no specific grant from any funding agency in the public, commercial, or non-for-profit sectors. 


\section{Data availability statement}

Data sharing is not applicable to this article as no new data were created or analysed in this study.

\section{Disclaimer}

The views and opinions expressed in this article are those of the authors and do not necessarily reflect the official policy of any affiliated agency of the authors.

\section{References}

Appel, K., Danz, C., Potz, R., Rosenberger, S. \& Walser, A. (eds.), 2012, Religion in Europa heute: Sozialwissenschaftliche, rechtswissenschaftliche und hermeneutisch-religionsphilosophische Perspektiven, V\&R Unipress, Wien.

Bader, V., 2009, 'The Governance of religious diversity: Theory, research, and practice', in P. Bramadat \& M. Koenig (eds.), International migration and the governance of religious diversity, pp. 43-72, McGill-Queen's University Press, Montreal. (Queen's Policy Studies).

Ballmer, D., 2019, 'Sozialdemokraten wollen die Religionen aus Basels Hinterhöfen rausholen', Zeitung für die Region Basel, 22 February, viewed 04 November 2019, from https://www.bzbasel.ch/basel/basel-stadt/sozialdemokraten-wollen-die-

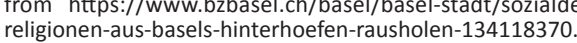

Baumann, M. \& Stolz, J. (eds.), 2007, Eine Schweiz - viele Religionen: Risiken und Chancen des Zusammenlebens, Kordula Röckenhaus, Bielefeld. https://doi. org/10.14361/9783839405246

Blume, M., 2017, Islam in der Krise: Eine Weltreligion zwischen Radikalisierung und Rückzug, Patmos, Ostfildern.

Bochinger, C. (ed.), 2012, Religionen, Staat und Gesellschaft: Die Schweiz zwischen Säkularisierung und religiöser Vielfalt, Zürich, NZZLibro.

Bramadat, P., 2009, 'Religious diversity and international migration: National and global dimensions', in P. Bramadat \& M. Koenig (eds.), International migration and the governance of religious diversity, pp. 1-26, McGill-Queen's University Press, Montreal.

Bühlmann, B., Bühler, W. \& Kessler, A. (eds.), 2009, Sachbuch religionen, Rex Verlag, Luzern.

Constitution of Hungary, 2011, On the right to freedom of conscience and religion and the legal status of churches, denominations and religious communities (Venice the legal status of churches, denominations and religious communities (Venice
Commission; Act CCVI), viewed 12 February 2019, from https://www.venice.coe. Commission; Act CCVI), viewed 12 February 2019, from https://www.venice.coe.
int/webforms/documents/default.aspx?pdffile=CDL-REF\%282012\%29009-e.

Constitution of Hungary, 2018, The Fundamental Law of Hungary of 25.04.2011, viewed 26 November 2018, from https://constitution.com/constitution-ofhungary/.

Constitution of the Republic of South Africa, 2019, Freedom of religion, belief and opinion of 1996, viewed 08 November 2019, from https://www.gov.za/

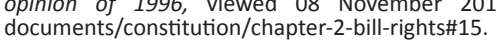

Doe, N., 2011, Law and religion in Europe: A comparative introduction, Oxford University Press, Oxford. https://doi.org/10.1093/acprof:oso/9780199604005. 003.0001

Durham, W.C. Jr., 2012, 'Patterns of religion state relations', in J. Jr. Witte \& M.C. Green (eds.), Religion \& human rights: An introduction, pp. 360-378, Oxford University Press, Oxford. https://doi.org/10.1093/acprof:osobl/9780199733453.003.0022.

Ecoplan, Ad!vocate, 2014, Das Verhältnis von Kirche und Staat im Kanton Bern, Eine Auslegeordnung, ecoplan, Bern.

Eidgenössische Kommission gegen Rassismus (ed.), 2003, Staat und Religion in der Schweiz: Anerkennungskämpfe, Anerkennungsformen, Eidgenössische Kommission gegen Rassismus, Bern.

Engi, L., 2017, Die religiöse und ethische Neutralität des Staates, Schulthess, Zürich.

Engi, L., 2018, Die staatliche Finanzierung von Religionsgemeinschaften, viewed 20 March 2019, from https://sui-generis.ch/article/view/sg.73/720.

Fisher, M., 2009, Spiritual guidance without all that religion, (The Star Phoenix, 02.05.2009), viewed 09 September 2013, from http://www2.canada.com/ saskatoonstarphoenix/news/world/story.html?id=6a433205-7093-448b-b61ed5be32aa3cb4.

Freikirchen.CH, 2019, Mitglieder, viewed 13 February 2019, from https://freikirchen. ch/organisation/mitglieder/.

Friedli, R. \& Schneuwly Purdie, M. (eds.), 2004, 'L'Europe des religions : Eléments d'analyse des champs religieux contemporains', in Studia Religiosa Helvetica, no. $8 / 9$, Peter Lang, Bern.

Göransson, A.., 2014, Contribution to the contributors of Society, in Transcript from the Swedish journal Kurage no. 14, 2014, The Commission for Government Support for Faith Communities, Bromma.

Habermas, J., 2018, Glauben und Wissen, 9th edn., Suhrkamp, Frankfurt am Main.

Hehli, S., 2018, 'Linke Frauen verlassen die Kirche - wegen der katholischen Frauenfeindlichkeit', Neue Zürcher Zeitung, 20 November, viewed 13 February 2019, from https://www.nzz.ch/schweiz/kirchenaustritt-linke-frauen-protestierengegen-papst-aussage-Id.1438053.
Inniger, M., 2016, 'A theological-ethical evaluation of the Christian-Muslim dialogue in the Swiss army chaplaincy', PhD thesis, North-West University, Potchefstroom, viewed 03 March 2019, from https://repository.nwu.ac.za/bitstream/ viewed 03 March 2019, from https://repository.nwu.ac.za/bits
handle/10394/19661/Inniger_M_2016.pdf?sequence=1\&isAllowed=y.

Inniger, M., 2017, Religionspolitische Herausforderungen und Handlungsoptionen des Kantons Bern: Eine Auslegeordnung erstellt im Auftrag der Justiz-, Gemeinde- und Kirchendirektion des Kantons Bern (Entwurf), 1 May 2017 (not published), JustizGemeinde- und Kirchendirektion des Kantons Bern, Bern.

Inniger, M., 2018, Religionspolitische Auslegeordnung für den Kanton Bern: Kurzbericht im Auftrag der Justiz-, Gemeinde- und Kirchendirektion des Kantons Bern (3 April 2018), Justiz-, Gemeinde- und Kirchendirektion des Kantons, Bern, viewed 03 March 2019, from https://www.jgk.be.ch/jgk/de/index/direktion/ueber-die03 March 2019, from https://www.jgk.be.ch/jgk/de/index/direktion/ueber-die-
direktion/dossiers.assetref/dam/documents/JGK/GS/de/Auslegeordnung $\% 20$ direktion/dossiers.assetref/dam/docu
Bernischen\%20Religionspolitik.pdf.

Inniger, M., 2019, 'Die Schweizer Armeeseelsorge und die Förderung des Religionsfriedens' Internationalen Kirchliche Zeitschrift, 2, viewed 10 November 2019, from https:// www.ikz.unibe.ch/pdf/Inniger_Armeeseelsorge_in_Internationale_Kirchliche_ Zeitschrift_2019.pdf.

Kanton Basel-Land, 2018, Kirchengesetz vom 3. April 1950 /17. Mai 1984 viewed 03 March 2019, from https://refbl.ch/refbl-wAssets/docs/KirchlicheGesetzessammlung/02-Staatliches-Kirchenrecht/2.1_-191-_kirchengesetz.pdf.

Kanton Basel-Stadt, 2019, Religionszugehörigkeit, viewed 12 February 2019, from https://www.statistik.bs.ch/zahlen/tabellen/1-bevoelkerung/religions https://www.statistik
zugehoerigkeit.html.

Kanton Bern, 2018a, Gesetz über die jüdischen Gemeinden vom 28.01.1997 (Status of 01 October 2018), viewed 27 November 2018, from https://www.belex.sites. be.ch/frontend/versions/1514/embedded_version_content.

Kanton Bern, 2018b, Präsentation des Berichts des Regierungsrates über das Verhältnis von Kirche und Staat im Kanton Bern 2015 (Leitsätze), viewed 27 November 2018, from https://www.be.ch/portal/de/index/mediencenter/ medienmitteilungen.assetref/dam/documents/portal/Medienmitteilungen/ medienmitteilungen.assetref/dam/documents/portal/Medienmitte
de/2015/03/2015-03-27-kirche-staat-referat-rr-neuhaus-mayer-de.pdf.

Kanton Bern, 2018c, Bericht über das Verhältnis von Kirche und Staat im Kanton Bern, Referat von Herrn Regierungsrat Christoph Neuhaus vor der Kommission für Staatspolitik und Aussenbeziehungen Bern, 18 Mai 2015, viewed 26 January 2018, from https://www.jgk.be.ch/jgk/de/index/direktion/direktor/die-referate/ 2018, from https://www.jgk.be.ch/jgk/de/index/direktion/direktor/die-referate/ Referate $\% 202015$.assetref/dam/documents/JGK/GS/de/Bericht $\% 20$
$\%$ C3\%BCber\%20das\%20Verh\%C3\%A4ltnis $\% 20$ von $\% 20$ Kirche $\% 20$ und $\% 20$ Staat $\% 20$ im $\% 20$ Kanton $\% 20$ Bern.pdf.

Kanton Bern, 2018d, Wording Protocol of the Parliament of the Canton Bern of the 10th September 2018, viewed 13 February 2019, from https://www.gr.be.ch/etc/ designs/gr/media.cdwsbinary.DOKUMENTE.acq/b8f891bce19840c5b Ofde8ef12291311-332/2/PDF/Tagblatt-D-175061.pdf.

Kanton Bern, 2018e, Dossier, viewed 03 March 2019, from https://www.jgk.be.ch/ jgk/de/index/direktion/ueber-die-direktion/dossiers.html.

Kanton Zürich, 2017, Staat und religion im Kanton Zürich, Eine Orientierung vom 29. November 2017, viewed 03 March 2019, from https://www.zh.ch/internet/de/ aktuell/news/medienmitteilungen/2017/leitsaetze-zum-verhaeltnis-zwischenaktuell/news/medienmitteilungen/2017/leitsaetze-zum-verhaeltnis-zwischenstaat-und-religionsgemeinsch/_jcr_content/contentPar/downloadlist/ Orientierung_Staat+und+Religion+KtZH.pdf.

Kleine, C. \& Wohlrab-Sahr, M., 2016, Multiple secularities - Beyond the West, beyond modernities, viewed 13 February 2019, from http://www.multiple-secularities.de/ Knippenberg, H., 1992, De religieuze kaart van Nederland, Van Gorcum, Assen.

Koenig, M., 2009, 'How nations-states respond to religious diversity', in P. Bramadat \& M. Koenig (eds.), International migration and the governance of religious diversity, pp. 293-322, McGill-Queen's University Press, Montreal. (Queen's Policy Studies).

Kymlicka, W., 2009, 'The governance of religious diversity: The old and the new', in P. Bramadat \& M. Koenig (eds.), International migration and the governance of religious diversity, pp. 323-334, McGill-Queen's University Press, Montreal. (Queen's Policy Studies.).

Madeley, J.T.S., 2003, 'A framework for the comparative analysis of church-state relations in Europe', in J.T.S. Madeley \& Z. Enyedi (eds.), Church and state in contemporary Europ, pp. 23-50, Routledge, London. (The Chimera of Neutrality). https://doi.org/10.1080/01402380412331300187

Madeley, J.T.S. \& Enyedi, Z. (eds.), 2003, Church and state in contemporary Europe, Routledge, Oxon. (The Chimera of Neutrality).

Pfaff-Czarnecka, J., 2009, 'Accommodating religious diversity in Switzerland', in P. Bramadat \& M. Koenig (eds.), International migration and the governance of religious diversity, pp. 225-257, McGill-Queen's University Press, Montreal. (Queen's Policy Studies).

Politik-Lexikon.AT, 2019, Diversität, viewed 14 February 2019, from http://www. politik-lexikon.at/diversitaet-diversity/.

Portier, P., 2017, 'Les regimes de laïcité en Europe', in A. Dieckhoff \& P. Portier (eds.), Religion et politique, pp. 211-222, Presses de SciencesPo, Paris.

Rechtsinformationssystem des Bundes (Österreich), 2019, Bundesrecht konsolidiert: Gesamte Rechtsvorschrift für 20009124 (Fassung vom 03.03.2019), viewed 03 March 2019, from https://www.ris.bka.gv.at/GeltendeFassung.wxe?Abfrage=Bun desnormen\&Gesetzesnummer=20009124.

Robbers, G. (ed.), 2005, State and church in the European Union, 2nd edn., Nomos, Baden-Baden.

Schuppert, G.F., 2017, 'Governance of diversity: Zum Umgang mit kultureller und religiöser Pluralität in säkularen Gesellschaften', Schriftenreihe Religion und Moderne 10, Campus Verlag, Frankfurt. 
Schweizerische Eidgenossenschaft, 2018, The Federal Constitution of the Swiss Federation, 18.04.1999, (Status as of 23 September 2018), viewed 03 March 2019 from https://www.admin.ch/opc/en/classified-compilation/19995395/index.html.

Statistics Netherlands CBS, 2018, Over half of the Dutch population are not religious, viewed 13 February 2019, from https://www.cbs.nl/en-gb/news/2018/43/overhalf-of-the-dutch-population-are-not-religious.

Stolz, F. \& Ballif, E., 2010, Die Zukunft der Reformierten: Gesellschaftliche Megatrends kirchliche Reaktionen, 2nd edn., Theologischer Verlag Zürich, Zürich.

Sweden, 2018a, 10 fundamentals of religion in Sweden, viewed 27 November 2018, from https://sweden.se/society/10-fundamentals-of-religion-in-sweden/.

Sweden, 2018b, The Swedish agency for support to faith communities, viewed 27 November 2018, from https://www.myndighetensst.se/om-oss/in-english.html.

Swiss Federal Supreme Court, 1992, Bundesgerichtsentscheide. (BGE 118 la 58), viewed 03 March 2019, from http://relevancy.bger.ch/php/clir/http/index. php?lang=de\&zoom $=\&$ type $=$ show document\&highlight_docid $=$ atf $\% 3 \mathrm{~A} \% 2 \mathrm{~F} \%$ 2F118-II-58\%3Ade.
Tagesschau.de, 2018, Papst vergleicht Abtreibung mit Auftragsmord, viewed 14 February 2019, from https://www.tagesschau.de/ausland/papst-abtreibung101.html.

United Nations, 2018, Universal declaration of human rights of 10 Dec 1948, viewed 01 December 2018, from https://www.ohchr.org/EN/UDHR/Documents/UDHR Translations/eng.pdf.

Van Bijsterveld, S., 2018, State and religion: Re-assessing a mutual relationship, Eleven International Publishing, The Hague.

Vorster, J.M., 2007, Christian attitude in the South African liberal democracy, Theological Publications, Potchefstroom.

Weller, P., 2005, Time for a change: Reconfiguring religion, state and society, T\&T Clark International, London/New York.

Wolterstorff, N.P., 2012, 'Christianity and human rights', in J. Witte \& M.C. Green (eds.), Religion and human rights, pp. 42-56, Oxford University Press, Oxford. https://doi.org/10.1093/acprof:osobl/9780199733453.003.0002 